\title{
AC 2012-4333: RETAINING MINORITY STUDENTS IN ENGINEERING: UNDERGRADUATE RESEARCH IN PARTNERSHIP WITH NASA
}

\section{Dr. Singli Garcia-Otero, Virginia State University}

Singli Garcia-Otero received M.S. and Ph.D. degrees in electrical and computer engineering from the University of Missouri, Columbia. She has three years industrial experiences as an engineer and has been teaching at different universities for more than 20 years. Currently, she is a professor in the Computer Engineering program at the Virginia State University.

\section{Dr. Eshsan O. Sheybani, Virginia State University}

Ehsan O. Sheybani has a Ph.D., M.S., and B.S. in E.E. from USF, FSU, and UF. Currently, Sheybani is Associate Professor at VSU. Research interests include communications and signal processing. Funded and published numerous times. 


\title{
Retaining Minority Students in Engineering: Undergraduate Research in Partnership with NASA
}

\begin{abstract}
Retaining underrepresented minorities in science, technology, engineering, and mathematics (STEM) is an essential step for increasing graduation rates and for meeting the demand for diversified and qualified STEM graduates. This demand has increased dramatically in recent years, especially with the retirement of baby boomers ${ }^{[1]}$. Therefore, the nation is facing a serious challenge in educating sufficient numbers of underrepresented minorities in the STEM fields to meet the demands of the scientific community.

There have been many studies on low retention rates among underrepresented minorities in STEM disciplines, and different conclusions have been drawn ${ }^{[2][3][4]}$. At Virginia State University, the most important factors for retention are the students' interest and motivation. In order to have high interest and motivation, students need to believe that a STEM major is worth the effort, that they have the ability to complete their degree, and that the degree is very useful for future employment.

In order to excite the students' interest and motivation, Virginia State University and Louisburg College partnered with NASA to create a summer internship at Goddard Flight Center, where eight undergraduates worked with NASA scientists on advanced electrical aeronautic projects. This paper documents the impact that this exciting partnership is having on the students.
\end{abstract}

\section{Background}

Virginia State University

Virginia State University is a Land Grant institution founded in 1882, located in Virginia, and is one of 104 Historically Black College and Universities (HBCU) in the United States. Approximately $95 \%$ of its more than 5,000 students are African American.

\section{Louisburg College}

Louisburg College is a private, co-educational, two-year residential college (the only two-year residential college in North Carolina, and one of only a handful in the United States). Founded in 1787, it is associated with the United Methodist Church, and offers three Associate degrees to its graduates: Associate in Arts, Associate in Science, and Associate in Science in Business. The school has an enrollment of approximately 700 students, including $70 \%$ African American.

Due to very limited advanced research opportunities for minorities in HBCUs, there is a scarcity of underrepresented minority engineers and scientists pursuing successful research careers in STEM. A serious national shortage of well-trained underrepresented minority engineers and scientists exits. Well-trained underrepresented minority engineers and scientists can conduct independent engineering research, can focus research on the disproportionate lack of technical achievement in minority populations, and have cultural perspectives that are essential to the successful conduct of many forms of research involving minority populations. 


\section{Partnership between Virginia State University, Louisburg College \& NASA}

In 2010, Virginia State University and Louisburg College were funded by NASA-CIPAR (Curriculum Improvement Partnership Award for the Integration of Research) for a project named "Establishing an Undergraduate Interdisciplinary Curriculum Incorporating NASA Related Research." One of the objectives of the project is to retain underrepresented minorities in STEM disciplines (especially in NASA-related geospatial science and technology) through the education and research components of an interdisciplinary curriculum, and specifically to motivate and encourage Louisburg College students to pursue and complete a four-year degree in STEM degrees at Virginia State University or other undergraduate colleges/universities. The ultimate goal is to increase the U.S. base of underrepresented minorities in NASA-related STEM professional level careers.

One of the components of the project is to involve students in NASA-related research through summer internships at NASA research centers such as GSFC (Goddard Space Flight Center).

In Spring of 2011, we invited a NASA scientist/engineer/mentor to give a talk to the students at Virginia State University about NASA-GSFC. More than thirty Virginia State University engineering students were interested in the internship. The five Virginia State University students were selected to participate in the internship.

\section{Internship in GSFC (Goddard Space Flight Center)}

During summer 2011, 5 Virginia State University and 3 Louisburg College students spent 8 weeks at GSFC and conducted 5 different research projects: Radar Signal Processing, FPGA Programming, Test Antenna in The Antenna Anechoic Chamber, Characterize a Compact Superconducting Channelizing Band-Pass Filter, and monitor the health of the riparian buffer zone along the Tar River.

The minority students gained valuable career experiences through the summer research internships which included high tech undergraduate research opportunities in NASA-related engineering and science fields. Following are some quotes from the students:

- Now that I know how to research and explore the concepts I need to know, nothing will stop me from learning.

- The days are coming closer and closer to an end here at NASA. I have had such a good experience here and have learned so much...

- ... I finally see how it feels to be a scientist; working long hours running tests only to have all of them fail. I realize now that I did not really fail; I simply found a way how not to build a control box....

- This time here at Goddard has been very exciting and informative. I got a chance to see how engineers work in such an important facility..... It is going to be a bittersweet feeling leaving here after next week.

- The most important thing I have learned is that everything done at NASA cannot be learned by reading a textbook. To open up your mind and explore new possibilities, you have to think outside the box. The things I learned at NASA, everyday people don't even 
talk about them because they can't even imagine them.

- I was interested in the things that NASA does. I wanted to gain experience in my field and this was a perfect opportunity to work with some of the best engineers around. I learned how certain things are proposed and done. I witnessed how engineers operate in the workforce.

- The most important thing I learned at NASA is to read. Plenty of times I was asked questions with the answer directly in my face, but I had not yet read what was in my face.

\section{Impact of Project}

This is only the first year of our project, but the impact is tremendous. Having gained high level experience and expectations at NASA Labs, the NASA summer internship students also gained a very positive attitude towards learning more at school. The new improved attitude towards learning has created a very positive atmosphere in the classroom for their classmates, as well as for their teachers. These students now understand more the need for grasping the hard concepts in math, science, engineering and technology. By talking about their experiences at NASA, these students are also motivating the rest of the class and encouraging them to try such internship opportunities. These students also continue their research in the Interdisciplinary Data Processing Lab at Virginia State University. Some of these students plan to expand their research into senior design projects. Furthermore, these students presented their projects in various professional conferences.

\section{The Future}

We have received another grant supporting NASA internships, which allows us to send more students to the NASA center the next summers, and will involve more students in the research. The students will bring back the NASA culture to the classroom, and we believe the retention rate will increase. This has also brought about a culture of "inquiry" to the engineering department, as students from all levels (freshman to senior) constantly inquire about availability of internships for summer and qualifications which they have to complete in order to get these positions. The new grant also provides major funding for establishing an advanced center for digital image processing which will sustain the undergraduate research in this field, as well as opens other doors for students to engage in signal processing research at a local level. This is especially important considering the new industrial developments in the vicinity of Virginia State University and the particular attention and need for skilled engineering graduates in this vicinity.

\section{Acknowledgment}

The authors would like to acknowledge NASA CIPAIR grant for the financial support.

\section{References}

1. U.S. Department of Labor, ftp://ftp.bls.gov/pub/special.requests/ep/indocc.matrix/occ_pdf/occ_17-2000.pdf

2. Felder R., Felder G., \& Dietz E., (2002) "The Effects of Personality Type on Engineering Student Performance and Attitudes,” Journal of Engineering Education, 91(1), 3-17. 
3. Flemming L., K.Engerman, \& D. Williams, (2006) "Why Students Leave Engineering: The Unexpected Bond," American Society for Engineering Education.

4. Seymour, E., \& Hewitt, N. (1997) "Talking About Leaving: Why Undergraduates Leave the Sciences," Boulder, Colorado: Westview Press.

5. Barger, M., Goff, G., \& Rogers, H. (2003) "Bridging a Gap: A.S. to B.S. Articulation in Florida," American Society for Engineering Education.

6. Newman, R., Munukutla, L., \& Robertson, J. (2002) "Building Bridges with Community Colleges, Partnering for Educational Success, " American Society for Engineering Education. 